PRZEGLĄD BIBLIOTECZNY 2020 z. 4

PL ISSN 0033-202X

MONIKA JANUSZ-LORKOWSKA

Wydział Dziennikarstwa, Informacji i Bibliologii

Uniwersytet Warszawski

e-mail: m.janusz-lorko@uw.edu.pl

ORCID: 0000-0002-4411-6537

\title{
KSIĄŻKA ZABAWKA - CIĄGLE NIEROZSTRZYGNIĘTY PROBLEM Z DEFINICJĄ POJĘCIA I WYODRĘBNIENIEM PODTYPÓW GATUNKU
}

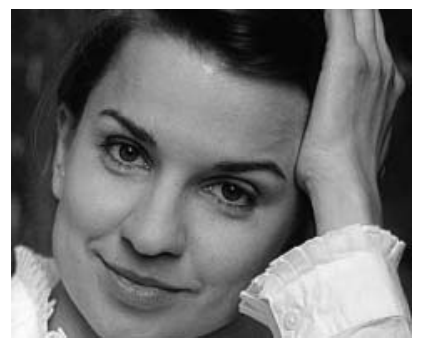

Absolwentka studiów na Wydziale Dziennikarstwa i Nauk Politycznych oraz w Instytucie Historii Sztuki UW. W przeszłości dziennikarka i recenzentka książek dla dzieci w „Rzeczpospolitej” i „Przekroju”, prowadząca autorską audycję „Biblioteka Małego Człowieka" w Polskim Radiu RdC. Obecnie doktorantka WDIB UW. Zainteresowania badawcze: promocja czytelnictwa wśród dzieci i młodzieży, książka dla dzieci, fotobook, relacje tekstu i obrazu w mediach.

SŁOWA KLUCZOWE: Książka zabawka. Książka pop-up. Typy książek dla dzieci. Rynek książek dla dzieci.

ABSTRAKT: Teza/cel artykułu - Celem artykułu jest przegląd dotychczasowych ujęć pojęcia "książka zabawka” w polskim środowisku badawczym oraz próba wyprowadzenia dla tego typu książki kolektywnej i jednorodnej definicji. Spiritus movens dla podjęcia takowych działań to problem z przeprowadzaniem badań dotyczących książki zabawki z powodu braku obowiązującej definicji pojęcia przedmiotu badań. Metody badań - analiza porównawcza, granulacja wiedzy na podstawie case study, indukcja i wnioskowanie aproksymatywne. Wyniki/wnioski - Badania na temat udziału i wielkości w rynku książki dziecięcej jej podtypu, jakim jest książka zabawka, były prowadzone w latach 2017-2019, ale konklu- 
zje z nich nie zostały wyciągnięte z powodu braku danych dot. książki zabawki w Polsce, co wynika przede wszystkim z faktu braku jednorodnej definicji książki zabawki.

Niniejszy artykuł powstał w efekcie próby przeprowadzenia badań ${ }^{1}$ dotyczących rynku książki dla dzieci w Polsce, a konkretnie tego jego segmentu, jakim jest tzw. książka zabawka. Od dłuższego czasu wśród wydawców i obserwatorów tendencji sprzedażowych istnieje przekonanie, iż w ostatnim dziesięcioleciu oferta na polskim rynku książki zabawki rośnie, poszerza się wachlarz jej typów oraz podtypów, oraz, że spotyka się ona z coraz większym zainteresowaniem nabywców. Gdy jednak spostrzeżenia te, artykułowane prima facie, zamierzano poddać konkretnym, liczbowym porównaniom dotyczącym tendencji związanych $\mathrm{z}$ podażą książki zabawki rok do roku, począwszy od stycznia 2000, aż po rok 2020, okazało się to niemożliwe do zrealizowania. Przeszkodą jest brak spójnego, jednoznacznego pojmowania książki zabawki jako takiej. Inne artefakty zaliczają do tej kategorii wydawcy, inne bibliotekarze, inne księgarze, a jeszcze inne jej nieliczni badacze (przykłady odmiennego rozumienia książki zabawki przez różnych uczestników komunikacji bibliologicznej w Polsce przedstawione zostaną poniżej)2 ${ }^{2}$. Definicji książki zabawki nie podają słowniki i encyklopedie, w tym specjalistyczne, jak np. Encyklopedia ksiązki wydana w 2017 r. przez Wydawnictwo Uniwersytetu Wrocławskiego.

By ustalić/objąć/opisać przedmiot badawczy, w artykule przedstawiony zostanie przegląd ujęć terminu książka zabawka obecny w polskiej literaturze bibliologicznej, lista jej typów i podtypów, a także wątpliwości związane $\mathrm{z}$ rozbieżnościami w wyjaśnianiu tego pojęcia. Następnie zaproponowana zostanie (do dalszych dyskusji wśród badaczy) wstępna koncepcja uniwersalnej definicji książki zabawki wraz z otwartym katalogiem/zbiorem jej rodzajów.

${ }^{1}$ Badania na temat udziału i wielkości w rynku książki dziecięcej jej podtypu, jakim jest książka zabawka, były prowadzone w latach 2017-2019, ale konkluzje z nich nie zostały wyciagnięte z powodu braku danych dot. książki zabawki w Polsce, co wynika przede wszystkim z braku jednorodnej definicji książki zabawki, o czym mowa będzie niżej w artykule.

2 "Komunikacja bibliologiczna (...) to proces wprowadzania książki do obiegu społecznego", także: „Komunikacja bibliologiczna per se jawi się jako system (makrosystem). Pewne podmioty biorące $w$ niej udział są swoistymi mikrosystemami, np. biblioteki i księgarnie. (...) Pomiędzy podmiotami biorącymi udział w komunikacji powstaje swoista sieć zależności (relacji), w której dochodzi/ może dochodzić do interakcji. Tak ujawnia się sieciowy charakter komunikacji bibliologicznej." Za: S.D. Kotuła: Komunikacja bibliologiczna wobec World Wide Web, Warszawa 2012, s. 114, 120. 


\section{KSIĄŻKA ZABAWKA - RÓŻNICE W POSTRZEGANIU}

Książkę zabawkę ma w swojej ofercie m.in. wydawnictwo Wytwórnia - jedna z najczęściej nagradzanych ${ }^{3}$ na arenie międzynarodowej polskich oficyn adresujących książkę do dzieci. Jak dotąd wszystkie wyróżnienia i medale otrzymała za publikacje typu kodeksowego, bez typowych cech książki zabawki ${ }^{4}$. Tymczasem $\mathrm{z}$ danych sprzedażowych prowadzonych przez wydawnictwo wynika, że najlepiej sprzedającymi się tytułami w 2019 r. były książki z serii Piżamorama francuskich autorów Frederique Bertrand i Michaela Leblond. Książki te, Piżamorama. Nowy Jork, Piżamorama. Paryż, Piżamorama. Moje Roboty oraz Piżamorama. Warszawa, to nic innego jak kierowane do najmłodszego odbiorcy (3+) książki zabawki. Ich autorzy, "dla zabawy", do której zapraszają czytelnika, wykorzystują $\mathrm{w}$ nich starą technikę animacji ombro cinema - wymyśloną ponad sto lat temu sztukę iluzji wykorzystującą stereografię. Na ilustracje stworzone metodą malowanych pastelowymi kolorami naprzemiennie jaśniejszych i ciemniejszych pasów, nakłada się folię typu „zebra” - z półprzezroczystymi paskami. Podczas poruszania folią po stronie odnosi się wrażenie, iż przedstawione na niej ilustracje „ożywają" - zwierzęta poruszają się, światła migocza, koła się toczą itd. Inne książki zabawki dostępne w księgarni wydawnictwa Wytwórnia ${ }^{5}$ to np. książka Psikusy! Małgorzaty Gurowskiej, Doroty Masłowskiej, Jacka Ambrożewskiego i in. ${ }^{6}$, o tym jak powstają psy

${ }^{3} \mathrm{~W}$ ostatnim dziesięcioleciu Wytwórnia otrzymała kilkanaście międzynarodowych nagród i wyróżnień, dominuje wśród nich Bologna Ragazzi Award, która jest międzynarodową nagrodą przyznawaną rokrocznie, od 1966 r., podczas targów książki Bologna Children's Book Fair w Bolonii, za najciekawszą na świecie, pod względem graficznym i edytorskim, książkę dla dzieci. Obejmuje kategorie: Fiction, Non Fiction, Opera Prima (dla niepublikowanych autorów i ilustratorów) oraz, od 2020 r., Comics. Wiecej o nagrodzie na: http://www.bookfair.bolognafiere.it/en/highlights/awards/bolognaragazzi-award/8382.html [online], [dostęp: 30.07.2020].

${ }^{4} \mathrm{O}$ cechach wyróżniających książkę zabawkę spośród innych będzie mowa w dalszych częściach artykułu; Książki, za które Wytwórnia otrzymała najwyższe nagrody to np. Julian Tuwim. Wiersze dla dzieci (ilustracje: M. Gurowska, M. Hanulak, M. Ignerska, A. Kucharska-Zajkowska, A. Niemierko, G. Urbańska-Macias, J. Wróblewska) - w 2008 r. złoto podczas międzynarodowych targów książki dla dzieci w Bolonii; ta sama nagroda w 2012 r. za tytuł Wszystko gra A. Czerwińskiej-Rydel i M. Ignerskiej, w 2015 r. za Wytwórnik Kulinarny K. Boguckiej i S. Tomiło, a w 2018 r. za Wytwórnik Góra! Madaleny Matoso. Więcej o wydawnictwie i tytułach, które otrzymały międzynarodowe nagrody: http://wytwornia.com/index.php/s/wyniki/k/typ/id/5 [online], [dostęp: 30.07.2020].

${ }^{5}$ Co nie jest jednoznaczne $\mathrm{z}$ faktem, że Wytwórnia jest ich wydawcą. Wśród kolejnych przykładów wydawcą książki zabawki Psikusy jest Gangdesign.

6 "PSIKUSY" to książka zabawka dla dzieci, sprzedawana w zestawie z kartonowymi klockami, której autorami są: Pani Jurek (autorka kryje się za pseudonimem, ale Jurek to jej prawdziwe nazwisko), Małgorzata Gurowska (koncepcja), Dorota Masłowska (wstęp/manifest), Jacek Ambrożewski, Marta Ignerska, Edyta Ołdak, Paulina Pankiewicz, Maria Strzelecka (ilustracje - wizerunki kundelków); Wydawca: Gangdesign (firma projektowa należąca do Pani Jurek), Warszawa 2016. O książce nota od wydawcy na potrzeby konkursu MustHave: „PSIKUSY to projekt o kundlach. Składa się z książki i klocków. Uczy dzieci, że piękno jest niezależne od rasy. To projekt o różnorodności, tolerancji także w kontekście ludzkim. Książka zawiera karty psów rasowych, autorstwa uznanych ilustratorów. Z wyciętych łap, głów, ogonów tworzy się kolaże. Wielość technik graficznych daje ogromną liczbę psich wariacji. Wśród klocków jest 5 ras, które można malować, kolekcjonować lub miksować na podobnej zasadzie". 
kundelki, a oparta na koncepcji książki zabawki typu dobieranki-ubieran$k i^{7}$, a także, w ofercie dla niemowląt - Pierwsza ksiażka Katsumi Komagata, typu kuferkowego (tu zamknięta w pudełku), składająca się z dwunastu czarno-białych, luźnych, niepowiązanych z sobą kart, przedstawiających figury i kształty zbudowane na bazie kontrastu barw. Jednak na pytanie skierowane do wydawnictwa o liczbę wydawanych rokrocznie tytułów typu książki zabawki, jego właścicielka Magdalena Kłos-Podsiadło odpowiedziała, iż nie sprzedaje zabawek i ma w swojej ofercie tylko książki.

W 2017 r. książki zabawki wprowadza na stałe do swojej oferty wydawniczej inna nagradzana w kraju i za granicą oficyna - największe wśród wydawnictw lilipucich ${ }^{8}$ - Dwie Siostry ${ }^{9}$. Mowa o serii książek, obecnie liczącej już siedem tytułów, typu pop-up (w polskiej literaturze przedmiotu określane są jako książki rozkładanki ${ }^{10}$ ). Wśród nich zarówno propozycje dla najmłodszych typu Co to za smutna mina? Élisy Géhin, jak i słynna, trójwymiarowa historia kolei dla dzieci nieco starszych (6+) - Ooodjazd! inżyniera papieru Gérarda Lo Monaco. Małgorzata Gałysz-Wróbel, z działu promocji wydawnictwa, zapytana o książki zabawki wskazuje właśnie na tę serię - klasycznych pop-up, i uznaje, że więcej książek typu „zabawki” jej oficyna w swojej ofercie nie ma. Tymczasem wcześniej, już w 2007 r., w 2014 i w 2016, Dwie Siostry wprowadzało na rynek i nadal ma w sprzedaży, interaktywne książki zabawki (polegające na uzupełnianiu treści przez czytelnika) polskich autorów, takie jak Świat jest dziwny Grażki Lange, Typogryzmoł Jana Bajtlika, czy Ksiażka do zrobienia Aleksandry Cieślak.

Prym w tym segmencie książki dziecięcej w Polsce wiodą jednak od lat 90. XX w. takie wydawnictwa jak: Olesiejuk (lider), Egmont, Ameet, AWM, Debit, Wilga i Publicat, co wykazywały w swoich badaniach Anna Sołtysiewicz $^{11}$ i Ewa Dąbrowska ${ }^{12}$. Według A. Sołtysiewicz udziały Wydawnictwa Olesiejuk w produkcji książki zabawki w latach 2000-2012 wynosiły niemal połowę rynku (48\%). A. Sołtysiewicz swoje dociekania oparła na analizie zbiorów zgromadzonych przez Bibliotekę Narodową do której każde z wydawnictw zobligowane jest przekazywać po dwa egzempla-

\footnotetext{
${ }^{7}$ Szerzej o typach książek zabawek w dalszej części artykułu.

${ }^{8}$ „Wydawnictwa lilipucie" - pojęcie spopularyzowane przez pisarkę i dziennikarkę Joannę Olech, a podchwycone przez badaczy (patrz: E. Jamróz-Stolarska, K. Biernacka-Licznar i N. Paprocka, Lilipucia rewolucja: awangardowe wydawnictwa dla dzieci i młodzieży w Polsce w latach 2000-2015: produkcja wydawnicza, bibliografia. Warszawa 2018) odnosi się do małych (prowadzonych często jedno-, dwuosobowo), niezależnych oficyn, powstałych w odpowiedzi na potrzeby rynku po 2000 r., publikujących książki obrazkowe o wysokim poziomie artystycznym, literackim i edytorskim.

${ }^{9} 26$ marca 2018 r. w Bolonii podczas największych targów książki dziecięcej na świecie, Bologna Children's Book Fair, Wydawnictwo Dwie Siostry ogłoszone zostało Najlepszym Europejskim Wydawcą Dziecięcym.

${ }^{10}$ Więcej o tym typie książki zabawki w dalszej części artykułu.

${ }^{11}$ A. Sołtysiewicz: Książki zabawki jako typ książki dla dzieci. Debiuty Bibliologiczno-Informatologiczne, t. 3. Kraków 2015, s. 34-36.

${ }^{12}$ E. Dąbrowska: Współczesna książka-zabawka w Bibliotece Jagiellońskiej. Bibliotheca Nostra. Ślaski Kwartalnik Naukowy, 2016, nr 1 (43), s. 167.
} 
rze wydawanych tytułów. Jednakże nie wszystkie oficyny wywiązują się $z$ tego obowiązku. Już ten fakt podaje $w$ wątpliwość oceny dotyczące ryn$\mathrm{ku}$, czynione $\mathrm{w}$ oparciu o rzekomo odzwierciedlające całą produkcję zasoby Biblioteki Narodowej. Ponadto, co zauważyła sama badaczka, nie wszystkie książki, które powinniśmy zaliczyć do książek zabawek, są tak przez pracowników Biblioteki Narodowej klasyfikowane. „Dzieła niektórych znanych światowych twórców książek zabawek zostały, owszem, zarejestrowane $\mathrm{w}$ katalogu komputerowym BN - pisze Sołtysiewicz - ale z powodu nieopisania ich hasłem „książka zabawka” nie znalazły się one w bazie BDKZ13. Są to np. książki Vojtěcha Kubašty i Roberta Sabudy ${ }^{14}$. Oznacza to, że w katalogu BN występuje prawdopodobnie znacznie więcej książek zabawek, niż w zbiorze, który opatrzono hasłem „książki zabawki". Sołtysiewicz nie wzięła ich w swoich badaniach pod uwagę „ze względu na zbyt dużą liczbę opisów bibliograficznych, które należałoby przejrzeć, a które nie wyróżniają się spośród innych książek żadną specyficzna, łatwą do wyszukania automatycznego cechą"15. Warto też pamiętać, że książki poniżej 16 stron nie są rejestrowane $\mathrm{w}$ „Przewodniku Bibliograficznym" BN, a książki zabawki często mogą mieć taką objętość.

Jednocześnie do kategorii „książki zabawki” są w Bibliotece Narodowej zaliczane tytuły, które A. Sołtysiewicz umieszcza w kategorii „wzbogacone”, typu: „z niezależnymi dodatkami”16. Są to najczęściej tradycyjne (w formie kodeksowej) książki obrazkowe, do których jednak, prawdopodobnie z powodów marketingowych, dołączany jest jakiś drobiazg - mazak, klocki, magnez, pluszak, grzebień, balonik itp. Książki „,z niezależnymi dodatkami", stanowiły aż 33\%(!) wszystkich analizowanych przez badaczkę tytułów wyszukanych pod hasłem książka zabawka w zbiorach Biblioteki Narodowej ${ }^{17}$. Tymczasem „niezależny dodatek” oznacza, iż zabawka

${ }^{13}$ BDZK - Baza Danych Książek Zabawek stworzona przez A. Sołtysiewicz na potrzeby jej badania.

${ }^{14}$ A. Sołtysiewicz, op. cit., s. 37; Książki twórców, których wymienia badaczka, należą do światowej klasyki książki zabawki z gatunku pop-up, czyli tzw. książek-rozkładanek. Vojtěch Kubašta był czeskim architektem i inżynierem. Zaczął projektować książki z trójwymiarowymi ilustracjami, ponieważ nie mógł w komunistycznych Czechach znaleźć zatrudnienia w swoim zawodzie. Jego talent w tej dziedzinie szybko został dostrzeżony również za żelazną kurtyną - realizował zamówienia m.in. dla brytyjskich i francuskich wydawnictw. Jego książki zostały opublikowane w 24 różnych językach i sprzedano je dotąd w 35 milionach egzemplarzy. Dziś oryginalne wydania jego ilustracji są poszukiwane przez kolekcjonerów z całego świata. Robert James Sabuda - amerykański artysta i inżynier papieru zaangażowany w projekty wprawiające papier w ruch. Międzynarodowe uznanie przyniosły mu szczególnie dwie wielkoformatowe, przestrzenne publikacje dla dzieci: Cudowny Czarnoksiężnik z Krainy Oz na podstawie powieści Franka Bauma, i Alicja w Krainie Czarów na podstawie powieści Lewisa Carrolla. Za, m.in.: https://blog.library.si.edu/blog/2009/10/28/n-9/\#.X19mRmczbwc, [online], [dostęp: 30.07.2020], https://web.archive.org/web/20040216192733/http://www.robertsabuda.com/sneakpeek/snpk0104-annbook.asp, [online], [dostęp: 30.07.2020], http://www.robertsabuda. com/, [online], [dostęp: 30.07.2020].

${ }^{15}$ Ibid., s. 34 .

${ }^{16}$ Szczegółowa klasyfikacja książek zabawek zaproponowana przez A. Sołtysiewicz zostanie przytoczona niżej.

${ }^{17}$ W sumie 33\% z 1168 książek zabawek wydanych w latach według stanu na 2015 r., na podstawie katalogu elektronicznego BN. 
w formie dodatku do książki, a przede wszystkim sama książka, mogą istnieć i prawidłowo „funkcjonować” niezależnie od siebie. Dołączony do książki gadżet nie jest potrzebny do jej odczytania i do obcowania z nia, tak jak ma to miejsce przy książkach zabawkach typu „,z elementami uzupełniającymi". Tu, dołączone do książki np. okulary 3D, są niezbędne dla odczytania trójwymiarowych ilustracji ${ }^{18}$, paskowana, plastikowa folia - do „poruszenia” obrazków przygotowanych w technice animacji ombro cinema, naklejki czy flamastry - do uzupełnienia treści i elementów książki w miejscach, w których zachęca do tego jej autor. Czy więc książki zabawki w wyodrębnionej przez A. Sołtysiewicz kategorii „wzbogacone” i opisane jako typ „z niezależnymi dodatkami” na pewno są książkami zabawkami?

Najwięcej wątpliwości mają wydawcy „zabawkowych” tytułów. Gdy w związku z nieścisłościami/niedoszacowaniem faktycznej liczby tytułów książek zabawek wydawanych w Polsce na podstawie li tylko zbiorów ujętych w katalogach Biblioteki Narodowej, a co wyjaśniono powyżej, podjęto próbę zbadania segmentu tego rynku książki dla dzieci inną metodą: na podstawie wywiadów zaadresowanych do kilkudziesięciu najważniejszych w Polsce wydawnictw ${ }^{19}$. Właściciele tych oficyn, bądź osoby oddelegowane do ich reprezentowania, nie byli jednak w stanie udzielić odpowiedzi na podstawowe/kluczowe pytania zawarte $w$ ankiecie ${ }^{20}$. Jednym $z$ takich pytań była prośba o liczbę wydawanych rokrocznie książek zabawek, w celu sporządzenia wykresów i przeprowadzenia analizy porównawczej, przyjrzenia się tendencjom podażowym. Większość wydawnictw odpowiadała, iż nie prowadzi statystyk produkcyjno-sprzedażowych z wyodrębnieniem segmentu książek zabawek. Te, które były przychylnie nastawione do badania (lub naciskane prośbą o odpowiedź), i chciały przyjrzeć się swoim tytułom pod tym kątem, przyznawały, że mają problem z definicją pojęcia - Jakie dokładnie książki mają zaliczać do książek zabawek? - pytano. Termin nie ma wyjaśnienia w ogólnie dostępnych słownikach i encyklopediach. Aleksandra Kabala z Wydawnictwa Olesiejuk dociekała, czy oprócz książek typu pop-up (rozkładanek), w wy-

${ }^{18}$ Przykładem takiej książki jest Jaś Ciekawski Matthiasa Picarda, wydany w Polsce w 2019 r. przez oficynę Kultura Gniewu. Patrz: https:/www.kultura.com.pl/web/index.php/komiks/104/jas-ciekawski.html [online], [dostęp: 30.07.2020].

${ }^{19}$ Grupę ankietowanych wydawnictw wyodrębniono na podstawie wskazań będących efektem wcześniejszych badań A. Sołtysiewicz: Książki rozkładanki w ofercie polskich wydawców. Bibliotheca Nostra. Ślaski Kwartalnik Naukowy, 2016, nr 3 (45) - to Olesiejuk, Egmont, Ameet, AWM, Debit, Wilga i Publicat; o odpowiedzi na pytania postawione w ankiecie (przede wszystkim o liczbę wydawanych książek zabawek) poproszono też wydawnictwa tzw. lilipucie, o których mowa m.in. w książce E. Jamróz-Stolarskiej, K. Biernackiej-Licznar i N. Paprockiej: Lilipucia rewolucja: awangardowe wydawnictwa dla dzieci i młodzieży w Polsce w latach 2000-2015: produkcja wydawnicza, bibliografia (Warszawa 2018).

${ }^{20}$ Badania dotyczące liczby wydawanych w Polsce książek zabawek, począwszy od roku 1992 do 2017, a także po zawężeniu tych dat - w okresie 2000-2018, próbowałam przeprowadzić w latach 2017-2020. 
dawaniu których to wydawnictwo przoduje ${ }^{21}$, do książek zabawek można zaliczyć te pozycje, do których dołączony jest drobny prezent/zabawka, tematycznie niekoniecznie powiązany z treścią książki. Miała więc dylematy podobne do tych, które mają pracownicy Biblioteki Narodowej, czasem zaliczający takie książki do książek zabawek, a czasem do tradycyjnych książek obrazkowych. Z kolei Marta Lenartowicz z wydawnictwa Wilga $^{22}$ oceniła, że książki zabawki stanowią ok. 30\% ich oferty. Miała jednak problem, jak zakwalifikować pozycje, które w jej wydawnictwie szeregowane są pod hasłem „książki aktywizujące”. Zaliczyła je do książek zabawek, ponieważ wymagają zaangażowania czytelnika w postaci uzupełniania treści za pomocą słów, liczb lub obrazków, często mają dołączone narzędzia dla takiej interakcji - flamastry, naklejki. Jednak wiele z tych książek nie posiada literackiej treści, a jedynie zadania i polecenia. Nie są to więc, de facto, książki do czytania, lecz raczej kolorowe zeszyty zadaniowe. Należy postawić pytanie - czy faktycznie można nazywać je książkami zabawkami?

\section{KSIĄŻKA ZABAWKA W POLSKIEJ LITERATURZE PRZEDMIOTU - PRZEGLĄD DEFINICJI I OPISÓW POJĘCIA}

Potrzeba znalezienia konkretnej definicji dla tego typu książki dla dzieci okazała się niezbędna do prowadzenia dalszych badań. Jednym z pierwszych odruchów przy poszukiwaniu znaczenia terminów bibliologicznych jest sięgnięcie do najnowszej specjalistycznej Encyklopedii książki, opracowanej $\mathrm{w}$ dwóch tomach przez kilkudziesięcioosobowy zespół ekspertów, a wydanej w 2017 r. przez Wydawnictwo Uniwersytetu Wrocławskiego. Hasło „,książka dla dzieci i młodzieży” opracowała tu badaczka Irena Socha. Opisy w Encyklopedii ksiażki skonstruowane są tak, iż odsyłają do siebie wzajemnie, jeśli tylko wyjaśnienie dla poszczególnych słów kluczy używanych dla danego hasła istnieje. I tak w haśle „książka dla dzieci i młodzieży", o rodzajach książki dla dzieci pod względem formy można przeczytać: „K. dz. w XIX i XX wieku rozwijała się w ścisłym związku z przemianami gatunkowymi literatury dla dzieci oraz sztuk ilustratorskiej i poligrafii, osiągając niezwykłe bogactwo form w rozmaitych gatunkach edytorsko-piśmienniczych: jako *k. obrazkowa dla najmłodszych; ${ }^{*}$ komiks; ${ }^{*}$ k. literacka; ${ }^{*}$ k. edukacyjna (*elementarz, ${ }^{*}$ podręcznik, *encyklopedia, gry edukacyjne), *k. dewocyjna (*Biblia, *modlitewnik, ${ }^{*}$ katechizm, *żywoty świętych); książka użytkowa (listownik, *poradnik dobrych

${ }^{21}$ Patrz badania i artykuł: A. Sołtysiewicz: Książki rozkładanki w ofercie polskich wydawców. Bibliotheca Nostra. Ślaski Kwartalnik Naukowy, 2016, nr 3 (45), s. 32.

${ }^{22}$ Obecnie wydawnictwo wchodzi w skład Grupy Wydawniczej Foksal GPW, powstałej w 2012 r, należącej do grupy kapitałowej, w ramach której działa sieć Empik. 
obyczajów, *kalendarz); śpiewnik; k.-zabawka (do składania, kolorowania, wycinania); książka ,ułatwiająca czytanie' (z dużą czcionką brajlowska). ${ }^{23 \prime \prime}$ Asterysku odsyłającego do rozszerzenia pojęcia w innym miejscu Encyklopedii... nie ma jednak przy kategorii książka zabawka. Hasło nie jest w Encyklopedii ksiażki wyjaśnione.

Książką zabawką interesują się niektórzy polscy badacze. Wskazywał na nią już Janusz Dunin, gdy stwierdzał m.in., że książki dla dzieci są skrajnym przykładem uzależnienia formy druku od jego odbiorcy, a najbardziej świadczą o tym książki zabawki ${ }^{24}$. Jednocześnie wskazywał na fakt, że bywają one dziełami sztuki i są ważnym dokumentem historii kultury, przy czym nie przewidywał ich dalszego rozwoju ${ }^{25}$. Nie zdefiniował też tego pojęcia ${ }^{26}$. Nie podjął się tego również kilkanaście lat później badacz Michał Zając, który na łamach fachowego pisma - „Poradnika Bibliotekarza", w interesujący sposób przybliżył krótko historię książki zabawki na świecie oraz zaprezentował najczęściej spotykane u rodzimych wydawców typy takich publikacjii ${ }^{27}$. „Książki zabawki - pisze jedynie we wstępie - to chyba najbardziej atrakcyjna wizualnie, frapująca i przykuwająca uwagę część oferty wydawniczej dla najmłodszych odbiorców. Często sądzi się, że są produktem najnowszych czasów. Nic bardziej błędnego! Pierwsze książki zabawki dla dzieci zaczęły pojawiać się w sprzedaży już od połowy XVIII w." ${ }^{28}$.

W pierwszych latach XXI w. krótko zdefiniowała je Małgorzata Chrobak. Nawiązując do koncepcji folkloru dziecięcego Jerzego Cieślikowskiego (ale nie do samej formy książki), opisała książki zabawki jako „twory, które (...) łączą w sobie określoną twórczość literacką adresowaną do dzieci lub na ich potrzeby adaptowaną literaturę dla dorosłych, z dziecięcym widzeniem świata” ${ }^{29}$. Na łamach „Guliwera” w prosty sposób przedstawiała książkę zabawkę Grażyna Lewandowicz-Nosal. Według niej to „przed-

${ }^{23}$ I. Socha, hasło: „książka dla dzieci i młodzieży”, W: Encyklopedia książki. Red. A. Żbikowska-Migoń, M. Skalska-Zlat, t. 2, Wrocław 2017, s. 112.

${ }^{24}$ J. Dunin: Ksiązeczki dla grzecznych i niegrzecznych dzieci: z dziejów polskich publikacji dla najmłodszych. Wrocław 1991, s. 103-105.

${ }^{25}$ Ibid., s. 165.

${ }^{26}$ Można by tu było odnieść się jeszcze, raczej polemicznie niż aprobatywnie, do koncepcji J. Dunina, przedstawionej w książce Rozwój cech wydawniczych polskiej książki literackiej XIX-XX wieku, według której wszystkie współczesne formy książki (w tym odpowiedniki współczesnych książek zabawek) pojawiły się $\mathrm{w}$ dwudziestoleciu międzywojennym. Polemika taka wymagałaby jednak sięgnięcia do historii książki zabawki jako takiej, która to wychodzi poza granice polskiego rynku, a do której nie sięga się tu intencjonalnie, ponieważ objętość artykułu na to nie pozwala, niemniej zagadnienie warto poruszyć w przyszłości w tekście odrębnym.

${ }^{27}$ M. Zając: Książki zabawki: długa historia i dzień dzisiejszy. Poradnik Bibliotekarza, 2008, nr 3 (dodatek), s. 1-4.

${ }^{28}$ Ibid., s. 1.

${ }^{29}$ M. Chrobak: Ksiażka czy zabawka, czyli o nowym rozdziale literatury dla dzieci. W: Sezamie, otwórz się! Z nowszych badań nad literatura dla dzieci i młodzieży w Polsce i za granica. Red. A. Baluch i K. Gajda. Kraków 2001, s. 50. 
miot wykorzystywany przez dzieci do zabawy, a łączący w sobie jednocześnie cechy i książki, i zabawki”30. W tym samym czasie (lata 2007-2008) Marek Kątny pisał o nich: „Chodzi tu o takie pozycje, które łączą walory konstrukcyjne z bogatą szatą edytorską uzupełnianą tekstem. Obejmują wydawnictwa wykorzystujące różne kształty zwierząt lub przedmiotów, z którymi dziecko styka się codziennie, a także takie, które zawierają na ilustracjach elementy ruchome, często trójwymiarowe, urządzenia mechaniczne bądź elektroniczne. Ich forma edytorska wskazuje, że stawiają sobie one na pierwszym miejscu cele poznawcze i kształcące" ${ }^{31}$. Rok później ciekawie o książkach zabawkach pisze Aleksandra Mochocka: „W kontakcie z najmłodszym odbiorcą książka, przedmiot stawiany przez wielu humanistów na piedestale, przejmuje często cechy i funkcje zabawki. Tego typu nowatorstwo formalne - książka zaprojektowana jako gra albo częściej zabawka - jest w obszarze literatury dziecięcej znana od średniowiecza. Ujmując rzecz historycznie, można wyróżnić rozbudowane instrukcje/opisy gier opowiadające historie (fabularyzowane), także publikacje z wmontowanymi zabawkami, kodeksy przyjmujące kształt zabawki czy $z$ ruchomymi elementami oraz książki grające/wydające dźwięki. A obecnie - publikacje na platformie elektronicznej. Synergiczny odbiór książki jako całości, złożonej tak z tekstu, jak i obrazu oraz nośnika o odpowiednim kształcie i specyficznej fakturze - jest naturalny (niejako organiczny, związany z psychologią rozwoju dziecka) i bywa następnie wykorzystywany jako zabieg formalny oraz/lub marketingowy"32. Dalej, odwołując się do definicji zabawy Kate Salen i Erica Zimmermana, dodaje: „Książki -zabawki motywują do podejmowania zabawy, możliwej wtedy, gdy czytelnik podejmie aktywną manipulację załączonymi elementami, zacznie je przestawiać i do pewnego stopnia przekształcać (np. spotykane na obszarze książki dziecięcej publikacje z elementami ruchomymi, tworzącymi kompozycje przestrzenne, jak Statek pirató $w^{33}$, z pozoru bardzo typowy, choć stylizowany na stara, okutą księgę kodeks, który daje się rozłożyć w makietę portu, karaibskiej wyspy oraz model galeonu, łącznie z masztem i bocianim gniazdem)" ${ }^{\prime 34}$.

Prób dookreślania książki zabawki w czasie najbliższym daty powstawania niniejszego artykułu, podjęły się badaczki: Agnieszka Maroń (2011 i 2014), A. Sołtysiewicz (w 2015) i E. Dąbrowska (w 2016). A. Maroń

\footnotetext{
${ }^{30}$ G. Lewandowicz-Nosal: Książki zabawki. Guliwer 2007, nr 1, s. 72.

${ }^{31}$ M. Kątny: Znaczenie książeczki-zabawki dla rozwoju osobowości dziecka w wieku przedszkolnym. W: VIII Kielecki Festiwal Nauki, 15-30 września 2007. Red. Z. Steciak, Kielce 2008, s. 97.

${ }^{32}$ A. Mochocka: Między interaktywnością a intermedialnością. Książka jako przestrzeń gry. Homo Ludens, 2009, nr 1, s. 162.

${ }^{33}$ Badaczka miała tu na myśli najpewniej książkę typu pop-up. najprawdopodobniej Statek piratów. Ksiażka z rozkładanymi obrazkami, autorstwo: Pat Hegarty, Brian Lee, Robin Wright, wydaną w roku 2005 przez Wydawnictwo Olesiejuk.

${ }^{34}$ A. Mochocka, op.cit., s. 163-164.
} 
w artykule Harmonijki, tarcze, klapki i żaluzje - ksiażka zabawka na przestrzeni dziejów stwierdziła: „Termin ksiażka zabawka wywołuje konotacje o charakterze ludycznym i jednoznacznie kojarzy się wszystkim odbiorcom z książką skierowaną do najmłodszego czytelnika, która w swej formie odbiega od postaci tradycyjnego kodeksu. Współczesny rynek księgarski dostarcza wielu najróżniejszych przykładów książki zabawki: od książek wytworzonych z papieru i tektury, przez takie, w których papier jest jedynie bazą do której dołączono elementy z innych tworzyw, aż do książek w całości wykonanych z tkaniny, pianki, czy plastiku" ${ }^{\prime 35}$. Po czym skupiła się na powstaniu i dziejach książki zabawki, w sposób ciekawy przedstawiła uznanych na arenie międzynarodowej twórców, opisała „sposób działania" wybranych modeli. W kolejnym tekście - Ksiażka zabawka na polskim rynku wydawniczo-ksiegarskim $w P R L-u^{36}$, przedstawia słynne serie i tytuły książek zabawek dla dzieci wydawanych w Polsce Ludowej. Pojęcia książka zabawka jednak nie wyjaśnia.

Anna Sołtysiewicz podejmuje temat książki zabawki także w dwóch artykułach, w tekście Ksiażki zabawki - definicje i podziat gatunkowy ${ }^{37}$, oraz w publikacji Ksią̇ki zabawki jako typ ksiażki dla dzieci. ${ }^{38} \mathrm{~W}$ pierwszym autorka wywodzi znaczenie pojęcia książki zabawki z jego słów składowych, cytując słownikowo-encyklopedyczne definicje wyrażenia „książka” oraz „zabawka”. Nie wyjaśnia jednak, niestety, co dokładnie oznacza związek frazeologiczny, który słowa te tworzą. Zauważa natomiast interesujący szczegół dotyczący tego terminu: „W literaturze przedmiotu spotyka się dwa niemal identyczne pojęcia: „książka-zabawka” i „książka zabawka”. Pomimo ich podobieństwa, można zaobserwować pewną istotną różnicę - łącznik występujący w pierwszym pojęciu wskazuje na to, że obie jego składowe są równorzędne. Tak więc pozycja taka jest w równej mierze książka, jak i zabawką. Budowa drugiego pojęcia sugeruje, iż przedmiot jest przede wszystkim książka, a w dalszej kolejności zabawką"39 (w niniejszym artykule książka zabawka jest rozważana zgodnie z wyjaśnieniem badaczki). Dalej autorka przywołuje definicje/opisy książki zabawki już istniejące i sygnalizuje mnogość typów tego rodzaju publikacji, co szczegółowo rozwija w artykule Książki zabawki jako typ ksiażki dla dzieci (w którym też jednak nie podaje jednej, konkretnej definicji książki zabawki).

Ewa Dąbrowska, która swoje badania, zawarte w artykule Wspótczesna książk-zabawka w Bibliotece Jagiellońskiej, oparła na zbiorach zgromadzo-

\footnotetext{
${ }^{35}$ A. Maroń: Harmonijki, tarcze, klapki i żaluzje - książka zabawka na przestrzeni dziejów. Bibliotheca Nostra. Ślaski Kwartalnik Naukowy, 2011, nr 4, s. 61.

${ }^{36}$ A. Maroń: Książka zabawka na polskim rynku wydawniczo-księgarskim w PRL-u. W: Literatura dla dzieci i młodzieży. Red. K. Heska-Kwaśniewicz, K. Tałuć. T. 4. Katowice 2014, s. 295-309.

${ }^{37}$ A. Sołtysiewicz: Książki zabawki - definicje i podział gatunkowy. W: Ksiażka, biblioteka, informacja: między podziałami a wspólnotą IV. Red. J. Dzieniakowska, M. Olczak-Kardas, Kielce 2015, s.

${ }^{38}$ Ibid.

${ }^{39}$ A. Sołtysiewicz, Ksiażki zabawki - definicje..., op. cit., s. 184.
} 
nych we wskazanej $\mathrm{w}$ tytule swojego tekstu bibliotece, oraz $\mathrm{w}$ oparciu o istniejące już w literaturze opisy ksiażki zabawki, tak o niej pisze: „Tym, co odróżnia książkę zabawkę od zwykłej książki, jest intencja wydawcy. Zakłada on dla swojej publikacji dwojakie wykorzystanie: do lektury jako nośnika treści słownych i graficznych, oraz do zabawy - jako atrakcyjny przedmiot, wykonany $\mathrm{w}$ celu pobudzenia aktywności ruchowej, umysłowej czy emocjonalnej. Angażuje i aktywizuje dziecko, które nie nabyło jeszcze umiejętności czytania. Uważa się, że książka zabawka jest skierowana do dzieci do szóstego roku życia. Najczęściej ma cechy typowe dla książki, czyli formę kodeksu, choć czasem od niej odchodzi. (...) Tekst, często tylko w formie krótkiego wyrażenia czy wręcz pojedynczego słowa, bywa tu jedynie dopełnieniem informacji zawartych $w$ formie graficznej, toteż w niektórych książkach zabawkach brakuje materiałów do analizy dla krytyka literatury. Z wymienionych względów książki takie zaliczane są do grupy utworów słownych paraliterackich, w których treść ma poboczne znaczenie, a istotna jest ilustracja oraz inne akcesoria towarzyszące, stanowiące o atrakcyjności produktu"40. Należy przyznać, że przedstawienie to jest dość wyczerpujące w porównaniu z wcześniej przytoczonymi.

Cytowani wyżej badacze przedstawiają pojęcie książki zabawki z różnych perspektyw, skupiając się na wybranych obszarach zagadnienia, ale, często intencjonalnie, nie wyczerpują całego spektrum zjawiska. $\mathrm{Z}$ tego powodu wiele $z$ tych definicji można podważyć. Na przykład proste i krótkie wyjaśnienie książki zabawki przez G. Lewandowicz-Nosal: to „przedmiot wykorzystywany przez dzieci do zabawy, a łączący w sobie jednocześnie cechy i książki, i zabawki" przestaje mieć rację bytu w zderzeniu z argumentami także wyżej cytowanej A. Mochockiej, która przekonuje, iż de facto każda książka może być zabawką: „Książka może być przedmiotem wykorzystywanym w każdym z typów zabaw. Wyobraźmy sobie rzut encyklopedią do celu, albo wyścigi ze stosem książek ustawionych na głowie - niczym w agonie ${ }^{41}$; wirowanie wokół własnej osi z ciężkim tomem w każdej ręce - illinx; wróżby z numerów przypadkowo otwieranych stron - jak w alea; Caillois przytacza przykład dzieci udających, że czytają książki - to mimicry"42. W podobnym duchu myślał o obcowaniu dzieci z książkami J. Dunin, gdy pisał, że dla najmłodszego czytelnika destrukcyjne podejście do lektury bywa zabawą - wręcz „,sensualną radością są pierwsze doświadczenia darcia kolorowego papieru..." 43 .

${ }^{40}$ E. Dąbrowska, op. cit., s. 162-163.

${ }^{41}$ Terminy zaznaczone kursywą w wypowiedzi badaczki odnoszą się do teorii gier, o których pisze w cytowanym tu artykule, a pochodzą z tekstu R. Caillois, Żywioł i ład. Warszawa 1973, s. 308-309.

${ }^{42}$ A. Mochocka, op. cit., s. 157.

${ }^{43}$ J. Dunin, op. cit., s. 15-19. 
Inne istniejące opisy, jak dość trafna i obszerna definicja książki zabawki M. Kątnego, czy też E. Dąbrowskiej, także nie rozwiewają niestety, wielu wątpliwości związanych z książką zabawką a dotyczących klasyfikowania poszczególnych tytułów jako książek zabawek. Czy książki wzbogacone o niezależne dodatki, na przykład o zabawkowy kuferek będący opakowaniem dla kodeksu, to faktycznie książki zabawki? Czy tytuły aktywizujące dziecko do samodzielnej pracy na ich poszczególnych stronach, poprzez dopisywanie, domalowywanie, doklejanie, wydzieranie, rachowanie etc., w sytuacjach, gdy zadaniom nie towarzyszy żadna fabuła/treść/opowiadanie ${ }^{44}$, należy zaliczać do książek zabawek, czy też może do zeszytów ćwiczeń/kodeksów zadań? Problem stanowią też książki, które zachęcają do zabawy za pomocą gadżetów/akcesoriów do nich załączonych, ale poza obszarem samej książki. Pisze o nich np. Anita Has-Tokarz w kontekście książek kucharskich dla najmłodszych. Często dołączane są do nich rozmaite akcesoria kuchenne, np. foremki do wypieków, a na stronach zawarte są związane z nimi zadania. A. Has-Tokarz zauważa, że interaktywność ${ }^{45}$ takich książek może odbywać się na dwóch poziomach - „wewnątrztekstowym” oraz „zewnątrztekstowym”. W książkach o interaktywności wewnątrztekstowej proponowane są rozmaite aktywności na łamach książki, takie jak gry, łamigłówki, naklejanie

\footnotetext{
${ }^{44}$ Jarosław Pacek badając znaczenie takich teoretycznie otwartych pojęć jak „,książka” oraz „książka elektroniczna", przy użyciu językoznawczej teorii pola semantycznego oraz kilkudziesięciu definicji istniejących w literaturze przedmiotu, skonkludował: „Obszar cech fizykalnych nie jest najistotniejszy dla zrozumienia czym jest książka jako taka. Cechy te nie są stałe, nie przenoszą wiedzy pozwalającej na odkrycie tego, co jest elementem wspólnym dla książki bez względu na jej typ. Wobec tego należy zadać pytanie: gdzie jest ukryta cecha/zespół cech stanowiących o idei ksiażki, pozwalających odróżnić książkę jako taką od innych obiektów informacyjnych, bez względu na to, jaka jej "odmianę" będziemy w danej chwili analizowali? Odpowiedzią na to pytanie będzie teza: wspólna, najważniejsza cecha książki (w ujęciu naukowym, definicyjnym) jest jej abstrakcyjna zawartość. Jest to zbiór konotacji wywołujących u odbiorcy książki wyobrażenie wiedzy, myśli, komunikatów i pojęć. Grupa słów związanych z abstrakcyjną zawartościa, choć stosunkowo nieliczna, uzyskała we wcześniejszych badaniach wysoką łączną częstotliwość. Była często przywoływana w definicjach, co świadczy o wysokim uznaniu dla tego składnika znaczenia książki. Dla aspektów abstrakcyjnych wspólnym określeniem pojawiającym się w dotychczasowych badaniach pola semantycznego książki jest słowo „DZIEŁO”. Patrz: J. Pacek: Pole semantyczne terminu „książka elektroniczna”. Zagadnienia Informacji Naukowej, 2016, z. 1, s. 104.

${ }^{45} \mathrm{O}$ znaczeniu pojęcia ksiażka interaktywna można przeczytać m.in. w artykule Wspótczesna ksiażka interaktywna dla dzieci na przykładzie twórczości Hervéa Tulleta Alicji Urban („,Acta Universitatis Wratislaviensis” No 3906/ „Studia o Książce i Informacji” 2018, nr 37, s. 163-175; DOI: 10.19195/23007729.37.12). Pisze ona: „Interaktywne książki są pierwszym krokiem do budowania nawyków czytelniczych u dzieci. Charakteryzują je nietypowe tekstury, ruchome elementy i kształty, które pozwalają zaciekawić dziecko, włączyć w lekturę oraz pomóc w rozwoju sensorycznym. Interaktywne książki wymagają zaangażowania, interakcji ze strony czytelnika. Mogą działać dzięki wykorzystaniu nowoczesnych technologii lub stosować rozwiązania edytorskie, które zaciekawia dziecko forma książki jako przedmiotu. Książki interaktywne służą wywołaniu pewnych zachowań i reakcji u dzieci, pobudzaniu kreatywności. Często wiąże się to z wykonywaniem zadań, dorysowywaniem kształtów na stronach, odtwarzaniem odgłosów według poleceń spisanych przez autora. W książkach interaktywnych dziecko bierze aktywny udział w "czytaniu” - nie tylko poprzez słuchanie czytanej przez rodzica czy opiekuna treści, ale często za sprawą możliwości samodzielnego decydowania o narracji, przebiegu wydarzeń".
} 
załączonych naklejek, wypełnianie szablonów zaproszeń i certyfikatów/ dyplomów „małych szefów kuchni”. „W wielu publikacjach zaprojektowano miejsca na rysunki i zapiski własnych przepisów czy menu - pisze badaczka. Są to przejawy interaktywności rozumianej jako idea akcji i kontrakcji: uczestnicy aktu komunikacji wpływają na siebie wzajemnie, co doprowadza do zmiany struktury tekstu. Czytelnicy mają też możliwość personalizowania egzemplarzy: wydawcy przewidzieli specjalne miejsce na wpisanie imienia i nazwiska właściciela, na przykład „Ta książka należy do...", „Moja pierwsza książka kucharska” itp. Dzięki tym rozwiązaniom stają się one osobistymi przepiśnikami"46. Niewątpliwie są to książki zabawki. W przeciwieństwie do tytułów o interaktywności „zewnątrztekstowej”, która, jak pisze A. Has-Tokarz, manifestuje się przez rozmaite aktywności kulinarne, ale poza strukturą książki. I choć aktywność ta/zabawa inspirowana jest książką i odbywa się przy pomocy zabawek/narzędzi do niej dołączonych, poniżej zaproponowana zostanie definicja, która wyłącza takie przypadki z "rodziny książki zabawki". Niewykluczone, że jest to propozycja nietrafiona, z pewnością dyskusyjna, może być jednak potraktowana jako zaproszenie do polemiki w tej kwestii, do wysuwania kolejnych konceptów, z nadzieją że ich suma może doprowadzić do spotkania/porozumienia w omawianej sprawie, co w przyszłości ułatwi pracę bibliotekarzy, wydawców, księgarzy i badaczy rynku książki dla dzieci. Zaznaczyć należy, że prowadzone tu rozważania dotyczące książki zabawki, oraz zaproponowana jej definicja, nie dotyczą stricte elektronicznych bytów takich publikacji ${ }^{47}$.

\section{KSIĄŻKA ZABAWKA - PROPOZYCJA DEFINICJI ORAZ OTWARTY ZBIÓR JEJ TYPÓW I PODTYPÓW}

Poprzez książkę zabawkę rozumiana jest tu taka wersja książki obrazkowej dla dzieci, która dzięki swej formie/konstrukcji wymaga aktywnego zaangażowania odbiorcy oraz dostarcza mu więcej możliwości manipulacyjnych, oraz wrażeń sensualno-wizualnych niż tradycyjna książka.

${ }^{46}$ A. Has-Tokarz: Przyjemność (z) konsumowania... Książki kucharskie jako element systemów rozrywki dla dzieci (konteksty kultury konsumpcyjnej i medialnej). Acta Universitatis Wratislaviensis, No 3982 „Literatura i Kultura Popularna” XXV, Wrocław 2019. s. 143; DOI: 10.19195/0867-7441.25.8.

${ }^{47}$ Za książkę stricte elektroniczną uważam, za M. Góralska, hasło: Książka elektroniczna. W: Encyklopedia książki. Red. A. Żbikowska-Migoń, M. Skalska-Zlat, t. 2, Wrocław 2017, s. 121: „dokument elektroniczny upodobniony do konwencjonalnej książki pod względem organizacji treści i funkcjonalności". Natomiast typy książek drukowanych i adresowanych do dzieci z kodami QR umożliwiającymi np. odsłuchanie określonych komunikatów czy obejrzenie powiązanych tematycznie krótkich filmów na ekranie domowego komputera czy smartfona, nie są publikacjami stricte elektronicznymi, lecz hybrydowymi, w których wersje papierowe są „rozszerzone” o wersje elektroniczne, a o których mowa np. w artykule A. Bożek i L. Kamińskiej-Mazur: Ksiażka hybrydowa-kod QR sposobem na koegzystencje ksiazki drukowanej z e-bookiem (w czasopiśmie fachowym. Biuletyn EBIB, nr 7 (134)/2012). Publikacje hybrydowe można zaliczyć do książek zabawek „wzbogaconych” ze względu na ich interaktywność. 
Co istotne, zgodnie z ideą literaturoznawcy i ludologa ${ }^{48}$ Jerzego Cieślikowskiego, książką zabawką w rozumieniu dosłownym powinien być nazywany przedmiot, którego cechy formalne na to wskazują zgodnie z intencjami twórcy/twórców. A więc są to książki, w których tzw. zabawowość jest „immanentną regułą samego dzieła, jego własną konstrukcją zrealizowaną w formie zabawki" ${ }^{49}$. Nie będą to więc książki wzbogacone o niezależne akcesoria, a bez których percepcja treści na ich stronach przebiega w sposób naturalny, pełny i bez zakłóceń. Książkę zabawkę można odróżnić od zabawki, czy też „kreatywnego zeszytu ćwiczeń”, dzięki jej treści literackiej lub paraliterackiej, mówiąc najprościej, dzięki temu, że o czymś opowiada. Do książek zabawek można dziś zaliczyć m.in.: książki przestrzenne i z ilustracją trójwymiarową (np. typu pop-up/rozkładanki, „magiczne oko", leporello, tunelowe/peepshow, z ilustracjami 3D), książki interaktywne, w tym hybrydowe ${ }^{50}$ (wymagające od czytelnika współtworzenia jej treści i zaangażowania manipulacyjnego, także w elektronicznych rozszerzeniach książki), wszelkie książki "przelotowe” („z otworem”, z „klapkami” zwane arlekinami), książki z ilustracją wprawianą w ruch (typu "pociagnij i porusz", w technice ombro cinema, volvelles, dobieranki/ubieranki, ,"z żaluzją"), książki typu „kuferkowego”, książki sensoryczne (oddziaływujące na zmysły nietypowym materiałem, fakturą, książki zapachowe, dźwiękowe, świecące, itp.).

O typach i podtypach książek zabawek pisali m.in. wspominani tu M. Zając, A. Maroń, E. Dąbrowska oraz, najbardziej szczegółowo - A. Sołtysiewicz. M. Zając i A. Maroń przyglądali się powstaniu i historii książki zabawki, w swych publikacjach powoływali się więc na jej najstarsze formy, opisywali konstrukcje najbardziej "pierwotne” dla tego gatunku (aczkolwiek nadal występujące). Są to książki takie jak:

1. Książki przestrzenne - przede wszystkim typu pop-up (ilustracja w nich, dzięki pracy inżynierów papieru, prezentuje się w sposób trójwymiarowy poprzez uniesienie się jej poszczególnych elementów po rozwarciu stronic), arlekiny ${ }^{51}$ (książki z dodatkową treścią ukrytą w okienku

${ }^{48}$ Obecnie termin ludologia odnosi się przede wszystkim do wszechstronnego badania gier, zwłaszcza komputerowych, swój źródłosłów ma jednak w łacińskim wyrażeniu ludus o znaczeniu „zabawa, rozrywka” oraz greckim logos. Terminu „homo ludens” (z łaciny, w dosłownym tłumaczeniu: „,człowiek bawiący się") używał już blisko 100 lat temu Johan Huizinga, przedstawiając w książce Homo ludens z 1938 r. koncepcję człowieka zakładająca, iż u podstaw każdego ludzkiego działania znajduje się zabawa. W tym sensie, w znaczeniu „,badacz zabawy i jej wpływu na literaturę” pozwalam sobie użyć określenia ludolog wobec autora m.in. Wielkiej zabawy, Jerzego Cieślikowskiego.

${ }^{49}$ J. Cieślikowski: Zabawa jako struktura pewnych tekstów literackich dla dzieci. W: Literatura osobna. Warszawa 1985, s. 65.

${ }^{50}$ Patrz przypis nr 45.

${ }^{51}$ Arlekiny to „niewielkie książki skonstruowane początkowo z połączenia dwóch kart, które po otwarciu ukazywały czytelnikowi na obu stronach po dwie otwierane klapki u góry i na dole. Dzięki takiemu rozwiązaniu, autor mógł przedstawić losy bohaterów nawet w 16 scenach, z których połowa skryta była za klapkami. Pierwszym dziełem Sayera tego typu był tytuł Adam i Ewa, który pojawił się na rynku ok. roku 1766. Cztery lata później wydawca znalazł innego bohatera, którego losy łatwiej 
„za klapką"), leporello (książka nie ma formy kodeksu, lecz harmonijki/ parawanu), tunelowe (dwa złożone w harmonijkę pasy papieru połączone są stronami okładkowymi, panoramiczne, wielopoziomowe ilustracje widoczne są przez otwór strony okładkowej, są powycinane z papieru i połączone z wewnętrznymi grzbietami harmonijki).

2. Książki ruchome - typu „pociągnij i porusz” (poprzez pociąganie za rozmaite tasiemki i paski papieru wprawia się w ruch elementy ilustracji - np. kończyny bohaterów opowieści), volvelle (koliste elementy wprawiane są $w$ ruch poprzez suwaki kołowe - sposób mocowania do strony), magiczne oko (ilustracje stworzone w taki sposób, iż w zależności od kąta patrzenia zmieniają swoje przedstawienie, a w trakcie tej zmiany następuje "ruch").

3. Książki szmacianki - tekstylne, wykonane z miękkich tkanin.

Ewa Dąbrowska uzupełniła te typy i podtypy o takie pozycje jak:

- wyprodukowane $\mathrm{z}$ innego niż papier materiału;

- dźwiękowe;

- książki-gry (grywalne), w tym puzzlowe;

- z ilustracją 3D - chodzi nie tylko o ilustracje typu pop-up, ale także o ilustracje, które należy oglądać przez okulary trójwymiarowe;

Anna Sołtysiewicz zaproponowała własny podział książki zabawki na kategorie, typy i podtypy. Warto zacytować tę klasyfikację w całości:

1. Ruchome, w tym: rozkładanki (w tym rozkładanki w pionie - upside-down), harmonijki (zwane leporello), metamorfozy, z otworami (w tym pozycje wyposażone w okienka, publikacje typu książki tunelowe-tunnel books i typu peepshow), z suwakami kołowymi (volvelle), arlekinady, "pociągnij i porusz" (typu pull-tabs), „dobieranki" (typu mix and match), „ubieranki" (typu paper-doll).

2. Wzbogacone: gry, z niezależnymi dodatkami ${ }^{52}$, z elementami uzupełniającymi, kolorowanki/uzupełnianki, do dotykania, ćwiczące spostrzegawczość (typu hidden object), interaktywne.

3. O nietypowym kształcie: $\mathrm{z}$ „,wykrojnika”, zawierające się w walizeczkach itp.

4. Niewykonane z papieru: gumowe, plastikowe, piankowe, materiałowe ${ }^{53}$.

Typów i podtypów książki zabawki jest wiele. Niektórym z nich badacze poświęcają odrębne publikacje (np. książce rozkładance, czyli pop-up, czy książce interaktywnej). Tu mnogość i bogactwo różnorodności ich

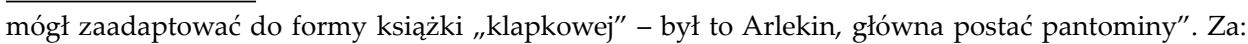
A. Maroń: Harmonijki, tarcze, klapki i żaluzje - książka zabawka na przestrzeni dziejów. Bibliotheca Nostra. Ślaski Kwartalnik Naukowy 2011, nr 4, s. 62.

${ }^{52}$ Przypomnieć należy, że tytuły wzbogacone o niezależne dodatki - niezależne w tym sensie, że zbędne dla odczytania treści książki, zostały wykluczone z rodziny książek zabawek w konstruowanym tu tekście.

${ }^{53}$ A. Sołtysiewicz: Książki zabawki jako typ ksiażki..., op. cit., s. 38-39. 
form jest ledwie zasygnalizowana. Szczegółowe opisy typów wymagają bowiem oddzielnego tekstu, przede wszystkim wizualizacji przy pomocy stosownych ilustracji przedstawiających omawiane przykłady. Niemniej zostanie niżej zaproponowany podział książki zabawki na typy i podtypy za pomocą diagramu, na podstawie propozycji cytowanych badaczy oraz nowych analiz oraz obserwacji, z zastrzeżeniem, iż jest to zbiór otwarty. Zapewne nie wszystkie typy książek zabawek zostały tu zawarte, ponadto $\mathrm{z}$ roku na rok ich przybywa.

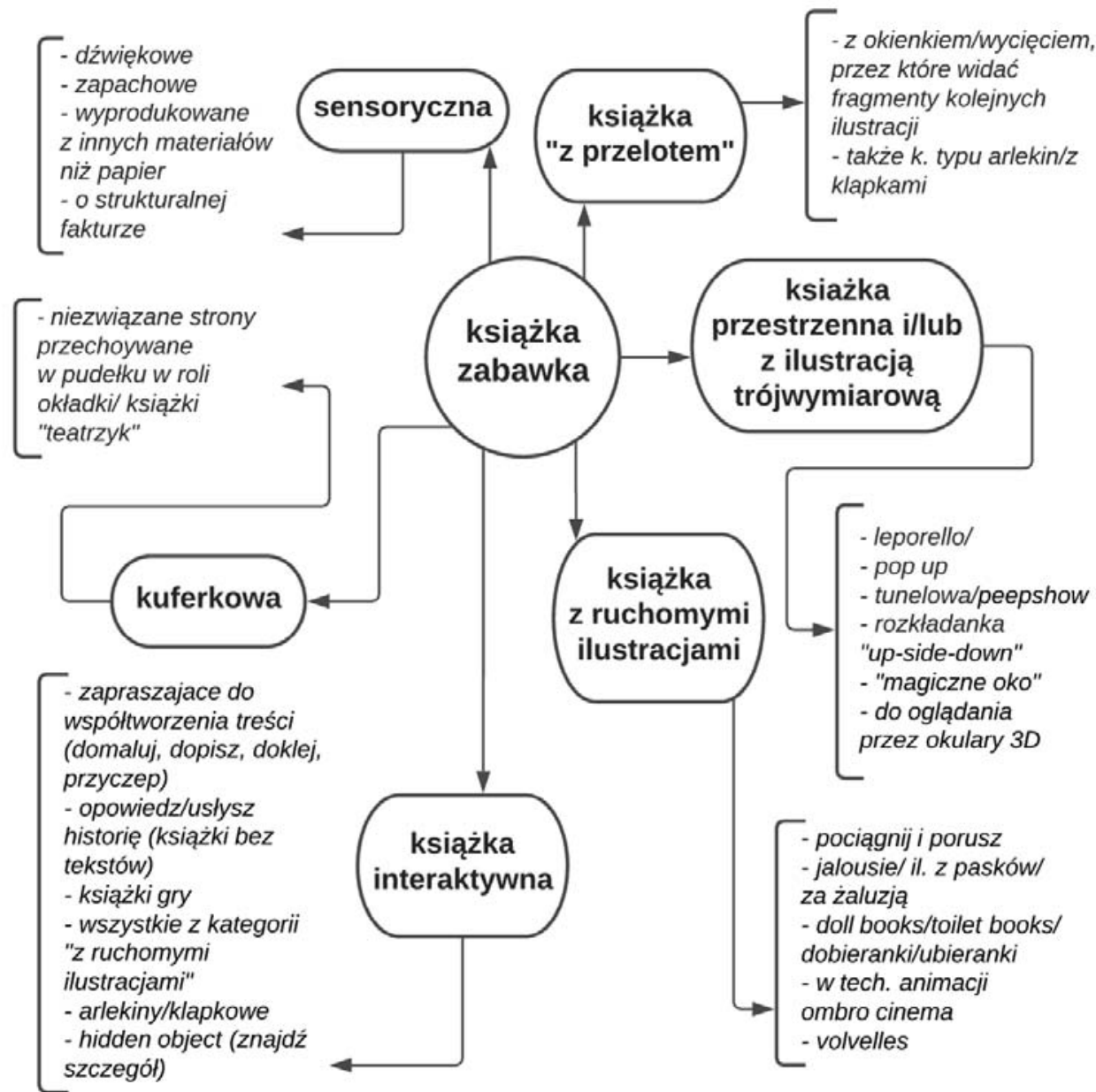

Źródło: oprac. własne. 


\section{PODSUMOWANIE}

Jakkolwiek niepoważna wydaje się być książka zabawka - bardzo często przecież „błyszczy i piszczy”, jest kierowana do najmłodszego, najczęściej nieumiejącego jeszcze czytać odbiorcy, jej treść rzadko jest przedmiotem badań i refleksji literaturoznawców, a nietypowa, odbiegająca od tradycyjnego kodeksu forma sprawia problem bibliotekarzom, chociażby w kwestii magazynowania, to jednak powinna być zbadana oraz zdefiniowana. Jest pojęciem pojemnym i coraz większym segmentem rynku książki dla dzieci. Zgoda co do faktu, które z przedmiotów o cechach zarówno książki, jak i zabawki, można klasyfikować do kategorii książek zabawek ułatwiłaby pracę bibliotekarzom i badaczom inicjacji czytelniczych. Istnieją już bowiem badania (co jest tematem na odrębny artykuł) potwierdzające, że aktywne zaangażowanie dziecka w obcowanie z lekturą - nie tylko w charakterze słuchacza, zwiększa szanse na wprowadzenie go do rodziny konsumentów książek. Książka zabawka jest najprawdopodobniej skutecznym czynnikiem wczesnej promocji kultury czytelniczej. Podczas gdy badacze studiują już dziś i definiują formę oraz zasięg oddziaływania takich tworów jak aplikacje książkowe, książka konwergencyjna, hybrydowa, intermedialna, transgresyjna ${ }^{54}$, które wszystkie powiązane są z cyfrową /elektroniczną postacią książki, ciągle nierozstrzygnięty jest problem z definicją pojęcia książki zabawki będącej u swego zarania dziełem analogowym. „Szeroko pojęta książka zabawka - jak trafnie pisze badająca ją pod kątem edytorskim Elżbieta Zarych - książka wzbogacona, nie funkcjonuje dziś jedynie w pokoju dziecięcym i na marginesie nauki, ale na pograniczu wielu dyscyplin: sztuki, edytorstwa, historii książki, literaturoznawstwa, pedagogiki, psychologii, projektowania, teorii gier, kognitywistyki, mediów, a także nauk społecznych i o komunikowaniu, stąd warto podejść do niej również interdyscyplinarnie" ${ }^{25}$.

\section{BIBLIOGRAFIA}

Chrobak, Małgorzata (2001). Książka czy zabawka, czyli o nowym rozdziale literatury dla dzieci. W: Sezamie, otwórz się! Z nowszych badań nad literatura dla dzieci i młodzieży w Polsce i za granica. Red. A. Baluch i K. Gajda. Kraków, s. 50.

Cieślikowski, Jerzy (1985). Zabawa jako struktura pewnych tekstów literackich dla dzieci. W: Literatura osobna. Warszawa 1985, s. 65.

${ }^{54}$ Książka transgresyjna jest pojęciem zaproponowanym przez autorkę artykułu w przygotowywanej dysertacji o roboczym tytule: „Transgresja formy książki dla dzieci jako czynnik promocji kultury czytelniczej".

${ }^{55}$ E. Zarych: Książka zabawka, książka wzbogacona. Wyobraźnia - obraz - sztuka edytorska. Bibliotekarz Podlaski 2018/3 (XL), 2018, s. 129-130. 
Dąbrowska, Ewa (2016). Współczesna książka-zabawka w Bibliotece Jagiellońskiej. Bibliotheca Nostra. Śląski Kwartalnik Naukowy, nr 1 (43).

Dunin, Janusz (1991). Książeczki dla grzecznych i niegrzecznych dzieci: z dziejów polskich publikacji dla najmłodszych. Wrocław.

Has-Tokarz, Anita (2019). Przyjemność (z) konsumowania... Książki kucharskie jako element systemów rozrywki dla dzieci (konteksty kultury konsumpcyjnej i medialnej). Acta Universitatis Wratislaviensis, No 3982 „Literatura i Kultura Popularna" XXV, 2019. s. 143; DOI: 10.19195/0867-7441.25.8.

Kątny, Marek (2008). Znaczenie książeczki-zabawki dla rozwoju osobowości dziecka w wieku przedszkolnym. W: VIII Kielecki Festiwal Nauki, 15-30 września 2007. Red. Z. Steciak. Kielce, s. 97.

Kotuła, Sebastian Dawid (2012). Komunikacja bibliologiczna wobec World Wide Web, Warszawa.

Lewandowicz-Nosal, Grażyna (2007). Książki zabawki. Guliwer, nr 1, s. 72.

Maroń, Agnieszka (2011). Harmonijki, tarcze, klapki i żaluzje - książka zabawka na przestrzeni dziejów. Bibliotheca Nostra. Ślaski Kwartalnik Naukowy, nr 4, s. 61.

Maroń, Agnieszka (2014). Książka zabawka na polskim rynku wydawniczo-księgarskim w PRL-u. W: Literatura dla dzieci i młodzieży. Red. K. Heska-Kwaśniewicz, K. Tałuć, t. 4. Katowice, s. 295-309.

Mochocka, Aleksandra (2009). Między interaktywnością a intermedialnością. Książka jako przestrzeń gry. Homo Ludens, nr 1, s. 162.

Pacek, Jarosław (2016). Pole semantyczne terminu „książka elektroniczna”. Zagadnienia Informacji Naukowej, z. 1.

Socha, Irena (2017). hasło: „,książka dla dzieci i młodzieży”. W: Encyklopedia książki. Red. A. Żbikowska-Migoń, M. Skalska-Zlat, t. 2. Wrocław, s. 112.

Sołtysiewicz, Anna (2015). Książki zabawki - definicje i podział gatunkowy. W: Książa, biblioteka, informacja: między podziałami a wspólnota IV. Red. J. Dzieniakowska, M. Olczak-Kardas, Kielce.

Sołtysiewicz, Anna (2015). Książki zabawki jako typ książki dla dzieci. Debiuty Bibliologiczno-Informatologiczne, t. 3. Kraków.

Urban, Alicja (2018). Współczesna książka interaktywna dla dzieci na przykładzie twórczości Hervéa Tulleta. Acta Universitatis Wratislaviensis No 3906 „Studia o Książce i Informacji” nr 37, s. 163-175.

Zając, Michał (2008). Książki zabawki: długa historia i dzień dzisiejszy. Świat Książki Dziecięcej - dodatek do „Poradnika Bibliotekarza”, nr 3, s. 1-4.

Artykut w wersji poprawionej wptynat do Redakcji 14 listopada 2020 r. 
MONIKA JANUSZ-LORKOWSKA

Faculty of Journalism, Information and Book Studies

University of Warsaw

e-mail: m.janusz-lorko@uw.edu.pl

ORCID: 0000-0002-4411-6537

\section{TOY BOOKS - UNRESOLVED PROBLEM OF THE DEFINITION AND SUBTYPES}

KEYWORDS: Toy books. Pop-up books. Types of books for children. Children book market.

ABSTRACT: Thesis/Objective - The aim of the article is to analyze definitions of "toy books" used so far by Polish researchers and attempt to provide and a comprehensive and homogeneous definition. The author decided to do that because of the problems with researching the subject due to the lack of the afore-mentioned definition. Research methods - The author used comparative analysis, knowledge granulation based on case studies, induction and approximate reasoning. Results/Conclusions - The research on the shares of toy books in overall book market in Poland was conducted in the years 2017-2019 but no conclusions were drawn mostly due to the lack of a homogenous definition of toy books. 